\title{
Review
}

\section{Electrochemical hydrogen compression and purification versus competing technologies: Part II. Challenges in electrocatalysis}

\author{
Marine Trégaro, Maha Rhandi, Florence Druart, Jonathan Deseure, Marian Chatenet* \\ Univ. Grenoble Alpes, Univ. Savoie Mont Blanc, CNRS, Grenoble-INP, LEPMI, 38000 Grenoble, France
}

\section{A R T I C L E I N F O}

\section{Article history:}

Received 20 May 2019

Accepted 3 July 2019

Published 5 May 2020

\section{Keywords:}

Electrochemical hydrogen compression Electrochemical hydrogen purification Electrocatalysts

Hydrogen oxidation

Poison tolerance

\begin{abstract}
A B S T R A C T
Hydrogen will be at the basis of the World's energy policy in forthcoming decades, owing to its decarbonized nature, at least when produced from renewables. For now, hydrogen is still essentially produced from fossil feedstock (and to a minor extent from biomass); in consequence the present hydrogen gas on the market is containing non-negligible amounts of impurities that prevent its immediate usage in specialty chemistry or as an energy carrier in fuel cells, e.g. in transportation applications (cars, buses, trains, boats, etc.) that gradually spread on the planet. For these purposes, hydrogen must be of sufficient purity but also sufficiently compressed (at high pressures, typically $70 \mathrm{MPa}$ ), rendering purification and compression steps unavoidable in the hydrogen cycle. As shown in the first part of this contribution "Electrochemical hydrogen compression and purification versus competing technologies: Part I. pros and cons", electrochemical hydrogen compressors (EHCs), which enable both hydrogen purification and compression, exhibit many theoretical (thermodynamic) and practical (kinetics) advantages over their mechanical counterparts. However, in order to be competitive, EHCs must operate in very intensive conditions (high current density and low cell voltage) that can only be reached if their core materials, e.g. the membrane and the electrodes/electrocatalysts, are optimized. This contribution will particularly focus on the properties electrocatalysts must exhibit to be used in EHCs: they shall promote (very) fast hydrogen oxidation reaction (HOR) in presence of impurities, which implies that they are (very) tolerant to poisons as well. This consists of a prerequisite for the operation of the anode of an EHC used for the purification-compression of hydrogen, and the materials developed for poison-tolerance in the vast literature on low-temperature fuel cells, may not always satisfy these two criteria, as this contribution will review.
\end{abstract}

(C) 2020, Dalian Institute of Chemical Physics, Chinese Academy of Sciences. Published by Elsevier B.V. All rights reserved.

\section{Introduction}

The so-called hydrogen economy is now on its way, as revealed by the numerous recent examples of vast demonstration programs in the United States of America (mainly in California - e.g. California Fuel Cell Partnership [1]), Japan (the recent launch of Toyota Mirai and Honda Clarity Fuel Cell, but also of the ENE-FARM small residential stationary program [2]) and more recently Europe ([3]). The common point with these programs is to attempt to widespread the usage of hydrogen, in the hope that it reduces our carbon footprint without compromising our technological development and way of living [4]. In order to be viable, this strategy must evidently rely on renewable (and therefore green) hydrogen (e.g. photovoltaic panels or windmills coupled to water electrolysis), which is not corresponding to the present situation. Indeed, hydrogen is pro-

\footnotetext{
* Corresponding author. E-mail: Marian.Chatenet@grenoble-inp.fr DOI: S1872-2067(19)63438-8 | http://www.sciencedirect.com/science/journal/18722067 | Chin. J. Catal., Vol. 41, No. 5, May 2020
} 
duced from fossil feedstock for more than $95 \%$ of its present worldwide production: steam reforming of methane is widely used for hydrogen production, and partial oxidation of natural gas is also possible. Other processes could also yield hydrogen: the Koppers-Totzek process (coal gasification) can produce rich hydrogen gas (97\%); biomass pyrolysis/gasification [5], dark fermentation [6] or photofermentation [7] of organic waste as well as photocatalytic degradation of organic matter [8] are being developed to produce "green hydrogen". In addition, natural emission of $\mathrm{H}_{2}$ on Earth exists, due for example to serpentinization reaction: however, $\mathrm{H}_{2}$-rich geological hydrogen (61.0 mol\%-87.3 mol\%) also contains $\mathrm{N}_{2}$ (less than 35 mol\%) and some $\mathrm{CH}_{4}$ (less than $20 \mathrm{~mol} \%$ ) [9].

None of the above-mentioned sources of hydrogen are sufficiently pure to enable their immediate usage in specialty chemistry or as an energy carrier in fuel cells [10]. For example, proton exchange membrane fuel cells (PEMFC) for fuel cell electric vehicles must use a very pure hydrogen gas: $\mathrm{H}_{2}>99.97$ mol\%, hydrocarbons $<2 \mathrm{ppm}$, CO $<0.2 \mathrm{ppm}$ (mol), sulfur compounds $<0.004 \mathrm{ppm}(\mathrm{mol}), \mathrm{NH}_{3}<0.1 \mathrm{ppm}(\mathrm{mol}), \mathrm{O}_{2}<5$ ppm (mol), $\mathrm{N}_{2}$ and $\mathrm{Ar}<100$ ppm (mol) [11]. Quite similar values can be found for stationary applications [12]. Besides purity, the hydrogen gas must also be sufficiently compressed (at high pressures, typically $70 \mathrm{MPa}$ ) to exhibit a competitive (volumetric and massic) energy density versus fossil fuels (e.g. gasoline, natural gas, etc.) [13]. These two examples show that purification and compression are unavoidable steps in the present hydrogen cycle, and if one wants to promote hydrogen fuel cell vehicles, it is not possible to rely on only large facilities for the production of pure and compressed hydrogen, but instead, numerous smaller hydrogen production, purification and compression units must be spread on the whole territory. The first part of this contribution "Electrochemical hydrogen compression and purification versus competing technologies - Part I: pros and cons", showed that electrochemical hydrogen compressors (EHCs) exhibit many theoretical (thermodynamic) and practical (kinetics) advantages over their mechanical counterparts for these applications. One of them is that EHCs enable both hydrogen purification and compression in a single device and at small scale without compromising the systems costs (of installation and of production) and performances (hydrogen purity, production rate, etc.). However, EHCs would only be competitive to their competing technologies provided they can operate in very intensive conditions: (very) high current densities above $j=2 \mathrm{~A} \mathrm{~cm}^{-2}$ or even $j=5 \mathrm{~A} \mathrm{~cm}^{-2}$, combined with low cell voltage (likely below $U_{\text {cell }}=0.5 \mathrm{~V}$ ) and high differential pressure per cell (likely $\Delta P=50-70$ bar). Reaching these performances would be desirable (if not mandatory) to make the EHC technology (economically) competitive, and they can only be reached if the EHC core materials, e.g. the membrane and the electrodes/electrocatalysts (essentially the anode), are optimized. For the cathode, as it should only be in contact with pure hydrogen gas and at higher pressure, the hydrogen evolution reaction should not be limiting. Thus, "regular" Pt electrocatalyst should be sufficient on this electrode and the EHC limitations will more probably be due to the sluggish hydrogen oxidation reaction (HOR) in presence of impurities and at low- er pressure, at the anode.

In that context, the present (and part II of this) contribution will particularly focus on the properties electrocatalysts must exhibit to be used in EHCs: because they shall promote fast HOR in presence of impurities, which implies that they are tolerant to poisons as well, the electrocatalysts materials must be tailored for the EHC application.

This consists of a prerequisite for the operation of the anode of an EHC used for the purification-compression of hydrogen, and the materials developed for poison-tolerance in the vast literature on low-temperature fuel cells (typically a PEMFC), may not always satisfy these two criteria, because in a PEMFC, the limiting electrode is the cathode and the hydrogen oxidation electrode does neither have to operate at high current densities (seldom above $j=2 \mathrm{~A} \mathrm{~cm}^{-2}$ ) nor at very large impurity content (see for example the following recent papers on the field [14-18]. Despite these limitations, these papers hold significant fundamental interest, and the following sections will largely make reference to past studies, in which the poisons have been tackled in PEMFC anodes.

\section{Electrocatalysts for the electrochemical purification-compression of hydrogen}

In an EHC as in a PEMFC, the electrocatalyst is usually supported on carbon (for electron percolation) and mixed with Nafion ${ }^{\circledR}$ ionomer (for proton percolation), and this blend is immobilized as porous active layers on each side of a proton-exchange membrane, to permit the reactions [19]. The reaction kinetics will depend on the nature of the electrocatalyst material, its morphology, and other environmental factors such as the cell temperature. To date, the best electrocatalyst known for the hydrogen oxidation reaction (HOR, which should proceed at the anode of an EHC) and the hydrogen evolution reaction (HER, which proceeds at the cathode of an EHC) in acidic environment is platinum. In order to reduce the capital cost of the cell, the use of Pt-based electrocatalyst must be decreased as much as possible, and one very easy manner to do so is to enhance its electrochemically active surface area (ECSA), by using nanoparticles [20]. The nanostructuration is however not possible down to any diameter, because (1) small nanoparticles (ultimately individual Pt atoms or small Pt clusters) are less stable than large ones (the well-known Ostwald ripening phenomenon destabilizes small objects at the expense of large ones [21,22]) and (2) the activity of nanoparticles may be altered for too small objects, a very classical result e.g. for the oxygen reduction reaction [23]; in consequence, a diameter of 4 $\mathrm{nm}$ was found to be the best compromise for platinum nanoparticles between the mass activity (for the oxygen reduction reaction) and the stability $([24,25])$. For the HER/HOR on Pt, such Pt nanoparticles size effect is not well documented; some authors claim yes [26] but this is not a matter of consensus, because this study was performed in liquid electrolyte conditions in thin-film rotating disk electrode, in which mass-transport limitations cannot be completely avoided, as discussed in [27]. Besides, in an electrochemical hydrogen purification/compression system, the (electro) catalyst layer on 
the anode side has to oxidize hydrogen in presence of impurities. Such impurities can have a very negative effect on the HOR performances, and require to use alternatives to pure Pt nanoparticles. The following sections will analyse the effects of each contaminant, and present the existing solutions to enhance the practical rate of the oxidation of impure hydrogen on Pt-based electrocatalysts.

\section{Effect of impurities on common PEMFC electrocatalysts}

As stated previously, one of the main objectives of the EHC is to produce pure hydrogen from an impure gas stream. In 2009, Besançon [28], described the reformate's contents for several sources of industrial hydrogen (Table 1). This set of data represents the feed stream that an EHC will have to purify; in other words, the high HOR current density mentioned in preamble of this contribution will have to be maintained, even in the presence of $\mathrm{CO}, \mathrm{CO}_{2}, \mathrm{CH}_{4}$, inert gases, and other impurities such as $\mathrm{NH}_{3}$ and $\mathrm{H}_{2} \mathrm{~S}$, which, as any electrochemist knows, is not granted.

As a matter of fact, the behaviour of an EHC in such environments has not been much studied yet. The literature, however, is rich with studies reporting experiments on the effect of reformate impurities on the HOR in PEMFC anodes. The experimental conditions experienced in a PEMFC anode and an EHC anode are quite similar: in both cases, the electrocatalyst layer is usually operated between $25^{\circ} \mathrm{C}<T<80^{\circ} \mathrm{C}$, shall maintain the lowest possible potential, and the majority of studies treat the case of $\mathrm{Pt} / \mathrm{C}$ or its derivatives. Three main differences should not be forgotten, though: in an EHC, there is no air at the cathode (and no $\mathrm{H}_{2} \mathrm{O}$ production), the cathode reaction (HER instead of the oxygen reduction reaction, ORR, in a PEMFC) is not limiting and the cathode pressure is much higher than at the anode one. Whatever these differences, these studies performed for PEMFC should provide a very precise idea of the expected effects of reformate impurities in an EHC system. The following sections address the possible effects of some impurities on the behaviour of an EHC anode.

\subsection{Inert gases}

In hydrogen reformate, small percentages of argon and ni-

\section{Table 1}

Composition of hydrogen streams from different production sources (given in \%). The water content of each stream was less than $250 \mathrm{ppm}$ [28].

\begin{tabular}{lccc}
\hline Component & Steam reforming & O $_{2}$-blown ATR & Coal gasification \\
\hline $\mathrm{H}_{2}$ & 94.3 & 93.2 & 87.8 \\
$\mathrm{CO}$ & 0.1 & 1.4 & 2.6 \\
$\mathrm{CO}_{2}$ & 2.5 & 1.7 & 3.9 \\
$\mathrm{~N}_{2}$ & 0.2 & 0.7 & 5.0 \\
$\mathrm{Ar}$ & 0 & 0.6 & 0.9 \\
$\mathrm{CH}_{4}$ & 2.9 & 2.4 & 0.01 \\
$T /{ }^{\circ} \mathrm{C}$ & 33.3 & 35.0 & 30.0 \\
$P / \mathrm{bar}$ abs & 26.3 & 25.0 & 28.0 \\
$Q / \mathrm{Nm}^{3} \mathrm{~h}^{-1}$ & 173318 & 17631 & 19402 \\
\hline
\end{tabular}

trogen can be found (Table 1). Although those gases are known to be inactive electrochemically, and thus, should have no impact on the catalyst layer, this fact is not granted; indeed, fuel starvation issues are common phenomena in dead-ended PEMFC anodes, in which crossover of $\mathrm{N}_{2}$ gas (and also of liquid $\mathrm{H}_{2} \mathrm{O}$ ) coming from the cathode side locally depletes the hydrogen content in the anode and has a deleterious effect on the cells performances and durability ([29-31]). A model was made by Um et al. [32] to estimate the influence of the hydrogen dilution by an inert gas. They showed that for a stoichiometry of 2.8 at $T=80^{\circ} \mathrm{C}$, and a current density of $j=1 \mathrm{~A} \mathrm{~cm}^{-2}$, the dilution has no effect on the cell performance, at least when the $\mathrm{H}_{2}$ content remains above $50 \%$ (Fig. 1). Below that value, the potential begins to drop significantly, at least for large current densities, revealing premature mass-transport limitations. PEMFC experiments confirm this result when the $\mathrm{N}_{2}$ concentration reaches 50\%-60\% [33-36]. One must emphasize that larger losses are expected for high current densities, so an EHC will be very sensitive to this effect. As a result, in the case of the EHC, the $\mathrm{H}_{2}$ inlet should not contain more than $6 \%$ of inert gases to enable the targeted performances $\left(j>1 \mathrm{~A} \mathrm{~cm}^{-2}\right)$. In addition, if a dead-end or multi-stage purification/compression method is chosen, larger dilution effects have to be expected and taken into account.

\section{2. $\mathrm{CH}_{4}$}

Methane can be found in very different proportions depending on the hydrogen inlet. Reformate hydrogen can contain up to $3 \% \mathrm{CH}_{4}$ [28], while if that inlet comes directly from natural gas (in which providers usually insert portions of hydrogen), $90 \%-95 \% \mathrm{CH}_{4}$ are expected. Unfortunately, the literature contains very little data on its effect on an EHC or a PEMFC system. In 2007, Ibeh studied the electrochemical separation of hydrogen from natural gas, and its efficiency [37]; more than $80 \% \mathrm{H}_{2}$ recovery was measured in a $25 \% \mathrm{H}_{2} / \mathrm{CH}_{4}$ gas, without any effect when changing the inlet flow. The same current densities were almost reached for dilutions of $8 \% \mathrm{H}_{2}$ in $\mathrm{CH}_{4}$ and for $8 \% \mathrm{H}_{2}$ in argon. When changing the temperature from $-30^{\circ} \mathrm{C}$ up to $45^{\circ} \mathrm{C}$, no more than $20 \mathrm{~mA} \mathrm{~cm}^{-2}$ of difference between the current limits were observed for a $25 \% \mathrm{H}_{2} / \mathrm{CH}_{4}$

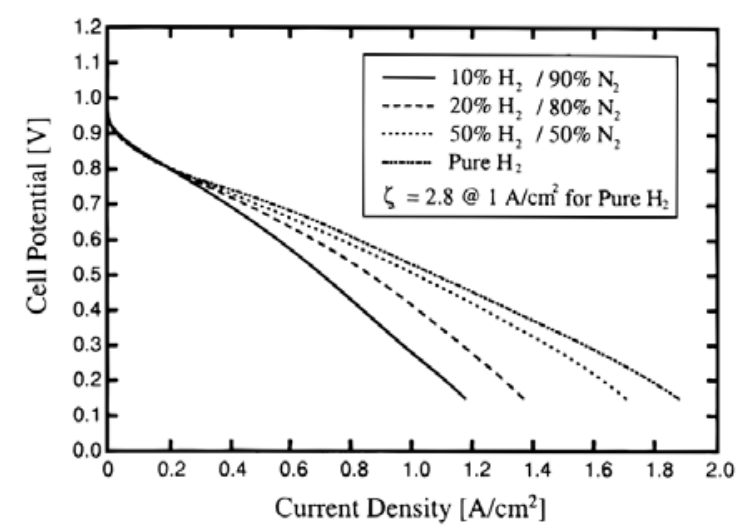

Fig. 1. Effect of inlet hydrogen molecular mole fraction for cell polarization curves with X_H20_cathode $=0$ (Um, 2000). 
flow. Chen, who worked at $140{ }^{\circ} \mathrm{C}$, also found no difference between the effects of $\mathrm{CH}_{4}$ and $\mathrm{N}_{2}$ at that temperature [38]. Methane therefore seems to act mainly as a diluent for hydrogen on Pt-based electrocatalysts, and will consequently have the same effect as those noted in section 3.1.

\section{3. $\mathrm{CO}_{2}$}

Contrary to the two previous gases, carbon dioxide was the centre of much more attention from researchers. $\mathrm{CO}_{2}$ is one of the main impurities contained in hydrogen reformate (Table 1), and its behaviour towards Pt-based electrocatalyst can be quite ambiguous: does it act as an inert gas, or does it poison the surface? In 1963, Giner [39] was one of the first to study the influence and mechanisms of $\mathrm{CO}_{2}$ towards low-temperature fuel cells operation. He found that $\mathrm{CO}_{2}$ has more than just a diluting effect towards hydrogen oxidation reaction. Fig. 2 shows $\mathrm{Gu}$ et al. [35] measurements on that matter: comparing the effect of hydrogen dilution with nitrogen and with carbon dioxide, they demonstrated the non-negligible difference between $\mathrm{CO}_{2}$ and an inert gas. Since this experiment was made with a cathode filled with pure hydrogen (hydrogen pump configuration), it is even more representative of the behaviour one could expect for the EHC.

This behaviour was thoroughly studied later on [36,39-41], and the hypothesis of the reverse water gas shift (RWGS) reaction seems to meet a common agreement. That reaction between $\mathrm{CO}_{2}$ and $\mathrm{H}_{2}$ is believed to occur in two places. Firstly, directly in the gas phase, when both gases are in contact (Eq. (1)). It was calculated that about 10-100 ppm CO were produced to reach the equilibrium. For a gas at $70{ }^{\circ} \mathrm{C}$ composed of $99 \% \mathrm{H}_{2}$ and $1 \% \mathrm{CO}_{2}$, Gu et al. [41] found that $10 \mathrm{ppm}$ of $\mathrm{CO}$ should be formed.

$$
\mathrm{CO}_{2}+\mathrm{H}_{2} \rightarrow \mathrm{CO}+\mathrm{H}_{2} \mathrm{O}
$$

The RWGS is also thought to be enhanced by the presence of the platinum (electro)catalyst, were $\mathrm{CO}_{2}$ seems to react with adsorbed-protons $\left(\mathrm{H}_{\mathrm{ad}}\right)$ to produce $\mathrm{CO}$ molecules, known to easily poison the Pt surface (detailed in section 3.5). Giner suggested Eqs. (2) and (3) to describe the mechanism.

$$
2 \mathrm{Pt}+\mathrm{H}_{2} \rightarrow 2 \mathrm{Pt}-\mathrm{H}
$$

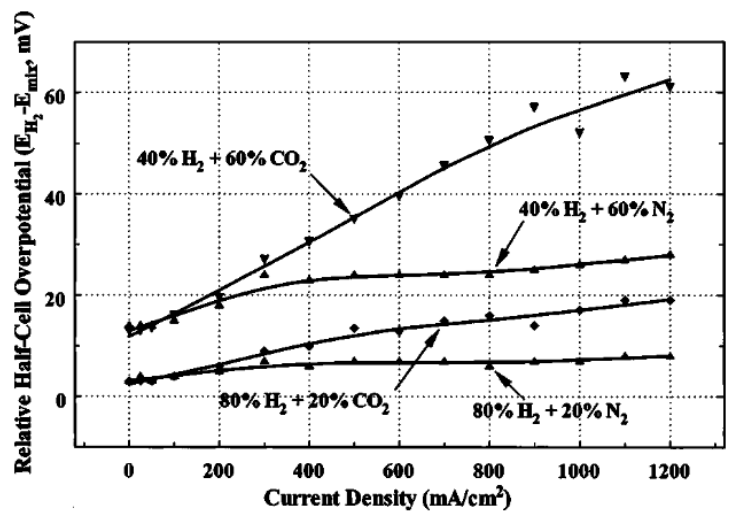

Fig. 2. Relative anode overpotential measured in half-cell configuration with $\mathrm{Pt} / \mathrm{C}$ anode and cathode electrocatalysts for the electrooxidation of $\mathrm{H}_{2}$ in various $\mathrm{CO}_{2} / \mathrm{H}_{2}$ and $\mathrm{N}_{2} / \mathrm{H}_{2}$ mixtures.

$$
\mathrm{CO}_{2}+2 \mathrm{Pt}-\mathrm{H} \rightarrow \mathrm{Pt}-\mathrm{CO}+\mathrm{H}_{2} \mathrm{O}+\mathrm{Pt}
$$

As seen in Fig. 2, and in Diaz et al. [42] work, the effect of carbon dioxide seems to worsen when its volume fraction in the gas increases. For instance, with a current density of $j=600$ $\mathrm{mA} \mathrm{cm}-2$, an overpotential $\eta=43 \mathrm{mV}$ is reached with $10 \% \mathrm{CO}_{2}$, and $\eta=62 \mathrm{mV}$ with $25 \% \mathrm{CO}_{2}$. However, because of the strong adsorption of $\mathrm{CO}$ on $\mathrm{Pt}$, $\mathrm{CO}$ production will decrease with the decreasing amount of available sites on Pt [43]. The effective adsorption of $\mathrm{CO}$ on the catalyst surface was studied by several groups [44,45], mainly through cycling-voltammetry measurements. The common CO-oxidation peak appeared with only $5 \% \mathrm{CO}_{2}$ in hydrogen. Some doubt still lingers however, concerning the exact nature of the adsorbate, Papageorgopoulos et al. [44] having found similar peak potentials with the presence of $\mathrm{COOH}$ or $\mathrm{CH}_{3} \mathrm{OH}$ in the electrolyte.

The effect of carbon dioxide on PEMFC performances are also dependent on the cell parameters. When increasing the cell temperature with a $25 \% \mathrm{CO}_{2} / \mathrm{H}_{2}$ inlet, Diaz et al. [42] measured an increase in the overpotential: from $\eta=50 \mathrm{mV}$ at $T=40^{\circ} \mathrm{C}$ to $\eta=60 \mathrm{mV}$ at $T=60^{\circ} \mathrm{C}$. They hypothesised that even though CO is better oxidized at high temperature (which is favourable), the CO production through the RWGS reaction also increases (which is highly detrimental): with a free enthalpy of $\Delta H=$ $-41.1 \mathrm{~kJ} \mathrm{~mol}^{-1}$, the RWGS reaction is endothermic, and thus is faster at high temperature $[46,47]$. Humidity was also found to be very influent in the presence of $\mathrm{CO}_{2}$ [48], probably by the improvement of $\mathrm{CO}$ oxidation. However, the huge influence of $\mathrm{H}_{2} \mathrm{O}$ on the common cell parameters such as ion conductivity or electrode flooding is hard to distinguish from its real effect on $\mathrm{CO}_{2}$ "poisoning".

With the EHC application, very high current densities are required. With a $25 \% \mathrm{CO}_{2} / \mathrm{H}_{2}$ inlet on a stack, Karimi et al. measured $0.5 \%$ potential loss at $j=0.1 \mathrm{~A} \mathrm{~cm}^{-2}$, and a much increased $12 \%$ potential loss at $j=1 \mathrm{~A} \mathrm{~cm}^{-2}$ [49]. The increase of the voltage penalty with current density is certainly non-negligible for high current densities that will be required in EHC systems, and this would probably be the case with each type of poison.

\section{4. $\mathrm{NH}_{3}$}

Ammonia can be formed by high temperature processes involving $\mathrm{N}_{2}$ and $\mathrm{H}_{2}$. In reformate, it is present in a 30-90 ppm range [28], and sometimes up to $150 \mathrm{ppm}$, according to Zamel et al. [46]. When present in the hydrogen mix, it decreases the cell potential in a non-negligible manner: $12 \%$ loss was recorded at $44 \mathrm{ppm}$ by Benesch et al. [50]. However, no effective loss was monitored with only $1 \mathrm{ppm}$ of ammonia, when Halseid et al. [51] found non-negligible effects. Effects on the catalyst layer were studied through cyclic voltammetry, and no difference was found whatever the $\mathrm{NH}_{3}$ concentration $[52,53]$. The main hypothesis to account for this surprising observation is that the overpotential increase is essentially due to an increase of the Ohmic drop, due to "damages" to the Nafion ${ }^{\circledR}$ membrane. Halseid et al. [51,54] measured the membrane resistance in presence of $\mathrm{NH}_{3}$, and found that the membrane conductivity decreases significantly with the $\mathrm{NH}_{3}$ content. According to the 
thermodynamics, $\mathrm{NH}_{3}$ is very soluble in $\mathrm{H}_{2} \mathrm{O}$, especially in acidic environment, and $\mathrm{NH}_{4}{ }^{+}$is easily formed. $\mathrm{NH}_{4}{ }^{+}$may replace protons on the sulfonic sites of the Nafion ${ }^{\circledR}$ membrane, and diminishes the overall membrane (and in particular proton) conductivity. However, the Ohmic drop does not entirely explain the overvoltage measured by these authors, and until now, no precise explanation has been provided to account for the other contributions.

In 2011, Imamura et al. [55] characterized the exhaust gas of a cell fuelled with hydrogen and $50 \mathrm{ppm} \mathrm{NH}_{3}$. Nearly no ammonia in the anode exhaust was detected, while $\mathrm{NH}_{3}$ and other nitrogen compounds were measured at the cathode exhaust (Fig. 3). As the oxidation of ammonia initiates at $E=0.7 \mathrm{~V}$ $v s$ RHE on Pt [56], it is possible that part of that gas, after crossing through the membrane (possibly in the form of $\mathrm{NH}_{4}^{+}$), has been oxidized at the cathode, resulting in poorer operation of the cathode.

When the anode is fuelled by pure hydrogen after a sequence of $\mathrm{NH}_{3}$ poisoning, the recovery does not depend on the amount of $\mathrm{NH}_{3}$ previously supplied, but on the time of that supply. A short-term poisoning, even with concentration as high as $200 \mathrm{ppm}$, can be recovered. However, a long-term poisoning with only $5 \mathrm{ppm}$ of ammonia, cannot be fully recovered [52,57]. Gomez et al. [57] suggested that after some time, the contact between the Pt nanoparticles and the ionomer is lost, leading to an irreversible loss of active surface area.

\section{5. $\mathrm{CO}$}

Carbon monoxide is a very common impurity present in hydrogen reformate, and has also a critical impact on platinum activity. Its effects on PEMFC have been thoroughly studied and modelled [58], and many parameters have been shown to influence the overall cell performances.

Carbon monoxide is known to adsorb very strongly on platinum, which blocks the catalysts sites for other reactions such as hydrogen dissociation and oxidation [28,33,47,50,59,60]. CO adsorption and oxidation mechanism is known to follow a Langmuir-Hinshelwood mechanism, corresponding to Eqs. (4) to $(6)[48,59]$.

$$
\mathrm{CO}+\mathrm{Pt} \quad \rightarrow \quad \mathrm{Pt}-\mathrm{CO}
$$

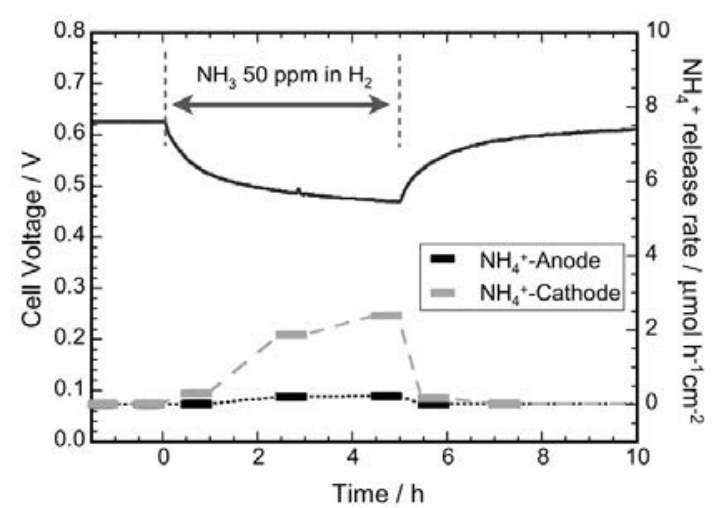

Fig. 3. Change in cell voltage and $\mathrm{NH}_{4}{ }^{+}$release rate from the anode and cathode exhaust. $\mathrm{NH}_{3}$ of $50 \mathrm{ppm}$ in $\mathrm{H}_{2}$ was supplied to anode under $j=$ $1000 \mathrm{~mA} \mathrm{~cm}^{-2}$ at $80{ }^{\circ} \mathrm{C}$

$$
\begin{aligned}
& \mathrm{Pt}+\mathrm{H}_{2} \mathrm{O} \rightarrow \mathrm{Pt}-\mathrm{OH}+\mathrm{H}^{+}+\mathrm{e}^{-} \\
& 2 \mathrm{Pt}-\mathrm{OH}+\mathrm{Pt}-\mathrm{CO} \rightarrow 3 \mathrm{Pt}+\mathrm{CO}_{2}+\mathrm{H}_{2} \mathrm{O}
\end{aligned}
$$

In most studies dealing with CO-tolerance in PEMFCs, the amounts of CO surveyed go from units to several hundreds of $\mathrm{ppm}$. In the case of an EHC, up to 2\% of CO can be expected, i.e. 20000 ppm (Table 1), a much higher proportion. Murthy et al. [60] worked with CO concentrations as high as $1 \%$, both at $T=$ $70{ }^{\circ} \mathrm{C}$ and $90{ }^{\circ} \mathrm{C}$ (Fig. 4). At a current density $j=1 \mathrm{~A} \mathrm{~cm}^{-2}$, a loss of nearly $0.5 \mathrm{~V}$ is found between pure hydrogen and $1 \% \mathrm{CO} / \mathrm{H}_{2}$ on a Pt-based electrocatalyst. As temperature increases the rate of $\mathrm{CO}$ oxidation, operating at higher temperature can reduce the poisoning effect for the same amount of carbon monoxide, but likely at the expense of the electrocatalyst durability [61]. Pressure seems to have only a slight amelioration effect on the poisoning, while Murthy et al. [60] and Cheng et al. [33] both found that for a higher current density, the cell potential decreases much faster.

Many techniques and materials have been studied to counter the effects of carbon monoxide poisoning. They will be developed in section 5 of this paper.

\section{6. $\mathrm{H}_{2} \mathrm{~S}$}

Hydrogen sulphide can be present in proportions up to 10 ppm in natural gas [62]. Just like CO, it can strongly adsorb on Pt surfaces and block active sites [63], which reduces the anode performances and therefore the cell voltage. Jayaram et al. [64] found two types of platinum-sulphur bond: at low coverage, there are mainly two-sites adsorption bonds, whereas at high coverage, only one-site adsorption bonds form. It was suggested that those adsorbates form platinum sulphides, through the mechanism presented in Eqs. (7)-(9) $[65,66]$.

$$
\begin{aligned}
& \mathrm{H}_{2} \mathrm{~S}+\mathrm{Pt} \rightarrow \mathrm{Pt}-\mathrm{H}_{2} \mathrm{~S} \\
& \mathrm{Pt}-\mathrm{H}_{2} \mathrm{~S} \rightarrow \mathrm{PtS}+2 \mathrm{H}^{+}+2 \mathrm{e}^{-} \\
& 2 \mathrm{PtS} \quad \rightarrow \quad \mathrm{Pt}+\mathrm{PtS}_{2}
\end{aligned}
$$

That corresponding active surface area loss was put into evidence by impedance spectroscopy (increase of the charge transfer resistance) [67], and by cyclic voltammetry [68]. In fact, the sulphur adsorbates can oxidize on Pt surfaces for $E>$ $0.8 \mathrm{~V} v s$ RHE [69], and part of the surface can be recovered by

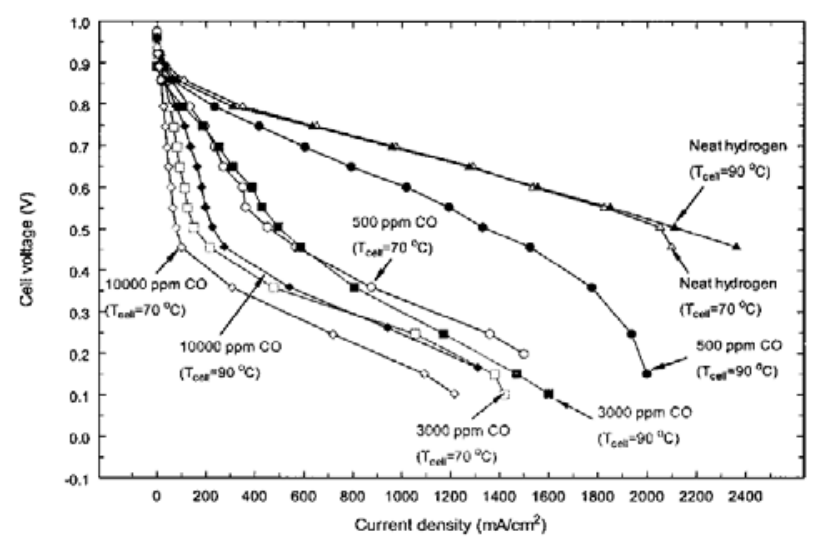

Fig. 4. Effect of the temperature on the performance of a PEMFC at $P=$ $202 \mathrm{kPa}$. Open symbols correspond to $T=70{ }^{\circ} \mathrm{C}$ and filled symbols correspond to $T=90{ }^{\circ} \mathrm{C}$. Concentration of $\mathrm{CO}$ in $\mathrm{H}_{2}$ : neat hydrogen $\boldsymbol{\Delta}$ and $\Delta ; 500 \mathrm{ppm} \bullet$ and $\circ ; 3000 \mathrm{ppm} \mathbf{a n d} \square ; 10000 \mathrm{ppm} \bullet$ and $\diamond$. 
such oxidation. However, this de-poisoning is partial and only part of the surface can be recovered; besides, the oxidation reaction consumes water from the membrane, which could reduce its ionic conductivity, especially in an EHC where there is no water production from the cell reactions (see the part I of the present contribution "Electrochemical hydrogen compression and purification versus competing technologies - Part I: pros and cons") [70].

Many groups studied the influence of the concentration of hydrogen sulphide on the cell potential $[50,71]$. With the increasing amount of poison, the overvoltage increases, and 2 ppm $\mathrm{H}_{2} \mathrm{~S}$ during $30 \mathrm{~h}$ caused a drop of $0.4 \mathrm{~V}$. Fig. 5 shows the influence of $\mathrm{H}_{2} \mathrm{~S}$ on cell voltage measured by Benesch et al. [50]. That poisoning phenomenon is also dependent on the cell temperature; it seems that the platinum-sulphur bond weakens at elevated temperature (a positive effect), but forms faster on the electrocatalyst surface (a negative effect) [70]; Urdampilleta et al. [71] measured a $69 \%$ increase in rate poisoning from 50 to $90{ }^{\circ} \mathrm{C}$ with $5 \mathrm{ppm} \mathrm{H}_{2} \mathrm{~S}$, which tends to demonstrate that the latter effect is predominant.

\subsection{Multiple gas}

The previous sections presented the effects of several individual gases on the HOR performances of a Pt-based electrocatalyst. Gas reformate, however, contains all the previously presented gases at the very same time. To put it in other words, the catalyst layer would have to bear multiple effects coming from $\mathrm{CO}, \mathrm{H}_{2} \mathrm{~S}, \mathrm{NH}_{3}$, and the possible dilution of $\mathrm{H}_{2}$ by these species and by the possible presence of (more) inert gases. Several groups studied the influence of several gas mixtures, in order to investigate an eventual synergetic effect due to their simultaneous presence.

Bhatia et al. [72] exposed a diluted hydrogen to 10-100 ppm of carbon monoxide, putting in evidence the vulnerability of the Pt surface in such a case. In fact, decreasing the hydrogen partial pressure worsens the poisoning by carbon monoxide, because the effect of site-inhibition by the poisons is magnified and lowers even more the surface coverage of free Pt sites for the HOR. The whole process was modelled, and the experimental results were confirmed [58,72,73].

In 2004, Janssen et al. [73] also calculated the effects of replacing $20 \%$ of $\mathrm{N}_{2}$ by $\mathrm{CO}_{2}$ in a $10 \mathrm{ppm} \mathrm{CO} / 40 \% \mathrm{H}_{2} / 40 \% \mathrm{~N}_{2}$ feed: the same current density loss was found, whether $\mathrm{CO}_{2}$ was

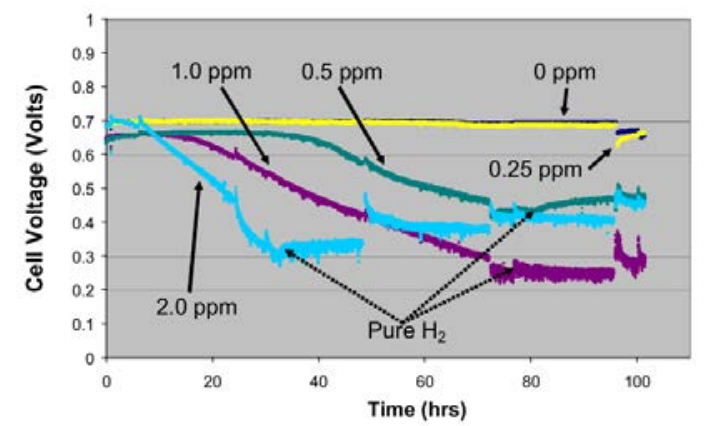

Fig. 5. Influence of $\mathrm{H}_{2} \mathrm{~S}$ in the $\mathrm{H}_{2}$ stream on the performances of a PEMFC [50]. present or not. This is in agreement with the hypothesis that the effect of $\mathrm{CO}_{2}$ resembles the effect of $\mathrm{CO}$ adsorption on the $\mathrm{Pt}$ surface, related to the RWGS equilibrium (see section 3.3).

When exposing a PEMFC to the two gases responsible for the worse poisoning effects, $\mathrm{CO}$ and $\mathrm{H}_{2} \mathrm{~S}$, Shi et al. [74] found strong performances loss, related the simultaneous adsorption of $\mathrm{CO}$ and sulphur compounds on the surface. The overall overpotential is however, slightly different to the sum of both contributions, emphasizing the adsorption of the two poisons are in competition for the same sites.

Lastly, Wang et al. [75] created a synthetic gas reformate mixture, made of several minor compounds that could be found in natural gas: $\mathrm{CO}, \mathrm{H}_{2} \mathrm{~S}$, formic acid, benzene, ammonia. When present in trace levels ( $4 \mathrm{ppb}$ for $\mathrm{H}_{2} \mathrm{~S}$ and $2 \mathrm{ppm}$ for formic acid), those impurities barely have any effect on the fuel cell performances, even after $200 \mathrm{~h}$ of operation. If those values are multiplied by five, however, the loss goes straight to $66 \mathrm{mV}$ for the same amount of time, and is partially irreversible.

\subsection{Countering impurities effect}

The previous sections demonstrate that hydrogen reformate contains impurities that can have very negative effects on the fuel cell performance; an EHC needing to operate at larger current densities than a usual PEMFC to remain competitive versus other purification/compression devices, it is expected that EHC devices will suffer even more from the presence of these impurities (possibly present in larger proportion than in a PEMFC feed). In order to keep the electrocatalyst HOR activity and reach current densities above $j=1 \mathrm{~A} \mathrm{~cm}^{-2}$, it is necessary to find materials and/or technical solutions to either recover or keep that current density at reasonable anode potential (and EHC cell voltage). Since the effects of these impurities have been discovered, many solutions were investigated and tested in various environments. Even though most were first dedicated to CO-poisoning, some can also be applied to other impurities. Two main possibilities can be distinguished: either recovering the initial state of components through a technical method, or enhancing the materials tolerance towards the poisons. These two strategies will be detailed below.

\section{Recovery techniques}

The most common recovery method, used almost after each study of the field, is to change the impurity-containing feed for a pure hydrogen feed (this strategy will not always be possible in practice). This is also used as a way to determine the possible reversibility of the poisoned state of the electrocatalyst. After carbon monoxide contamination, changing for a pure $\mathrm{H}_{2}$ inlet seems to free most of the Pt surface $[42,74]$. After more than $3 \mathrm{~h}$ with $9 \mathrm{ppm}$ of $\mathrm{CO}$, Benesch et al. [50] recovered up to $95 \%$ of the initial cell voltage with $5.5 \mathrm{~h}$ with a pure $\mathrm{H}_{2}$ inlet at the anode. It is not known if the positive recovery maintains for longer operation under impure $\mathrm{H}_{2}$ or larger $\mathrm{CO}$ contents.

Sulphur-contaminated surfaces however, do not show such positive results [71]. Applied to a $\mathrm{H}_{2} / \mathrm{CO} / \mathrm{H}_{2} \mathrm{~S}$ mixture, this method can only recover the surface lost with $\mathrm{CO}$, emphasising 
the irreversibility of the $\mathrm{H}_{2} \mathrm{~S}$ poisoning. Fig. 6 shows results obtained by Shi et al. [74] on that matter. Imamura et al. [76] and Urdampilleta et al. [71] tried to fix the open-circuit potential during pure $\mathrm{H}_{2}$ feed, getting the initial current back even with 2 ppm $\mathrm{H}_{2} \mathrm{~S}$. A hypothesis for this recovery was that it could be due to partial sulphur oxidation at the cathode. This cannot be applied in the EHC case however, since oxygen is not present at the cathode, and the pressure difference between the two electrodes should prevent any crossover of the impurities (fortunately, as it is at the basis of the purification targeted using an EHC). As for the case of ammonia, recovery by pure $\mathrm{H}_{2}$ inlet depends on the duration of $\mathrm{NH}_{3}$ feed, as explained in section 3.4

"Air bleeding" or " $\mathrm{O}_{2}$ bleeding" is another method used to reduce the effects of $\mathrm{CO}$ contamination. It consists of injecting a small amount of oxygen (or air), into the anode feed $[36,42,46,47,49,77,78]$. Oxygen adsorbs on Pt, in order to oxidize CO. Eqs. (10) to (12) explain the mechanism at work. Towards $25 \% \mathrm{CO}_{2}$, Karimi et al. [49] achieve significant decontamination with only $0.5 \%$ to $4 \%$ of oxygen. Adcock et al. [79] created a reconfigured anode with that process in mind, adding a catalyst layer upstream the electrocatalyst layer (this one being positioned onto the membrane) to directly oxidize carbon monoxide with cheap materials (in an heterogeneous catalysis process) prior it can reach the electrocatalytic layer, which overall minimizes the effect on the Pt-based electrode. At high current densities however, introducing oxygen is not as effective anymore. At $j=1 \mathrm{~A} \mathrm{~cm}^{-2}$ with a $0.3 \% \mathrm{CO} / \mathrm{H}_{2}$ feed, even a $15 \%$ air bleed was not enough to protect/recover the electrocatalyst surface $[60,80]$. Also, some dioxygen molecules can react with dihydrogen, and reduce the overall system efficiency by decreasing the amount of hydrogen. This technique was also applied on $\mathrm{H}_{2} \mathrm{~S}$ and $\mathrm{NH}_{3}$, with no positive effect $[57,81]$.

$$
\begin{array}{rlc}
\mathrm{O}_{2}+2 \mathrm{Pt} & \rightarrow & 2 \mathrm{Pt}-\mathrm{O} \\
\mathrm{Pt}-\mathrm{O}+\mathrm{Pt}-\mathrm{CO} & \rightarrow & 2 \mathrm{Pt}+\mathrm{CO}_{2} \\
\mathrm{Pt}-\mathrm{O}+2 \mathrm{Pt}-\mathrm{H} & \rightarrow & 3 \mathrm{Pt}+\mathrm{H}_{2} \mathrm{O}
\end{array}
$$

Another attempt to recover the initial surface was to apply periodic pulses to the cell. Gardner et al. [82] tried to apply 10

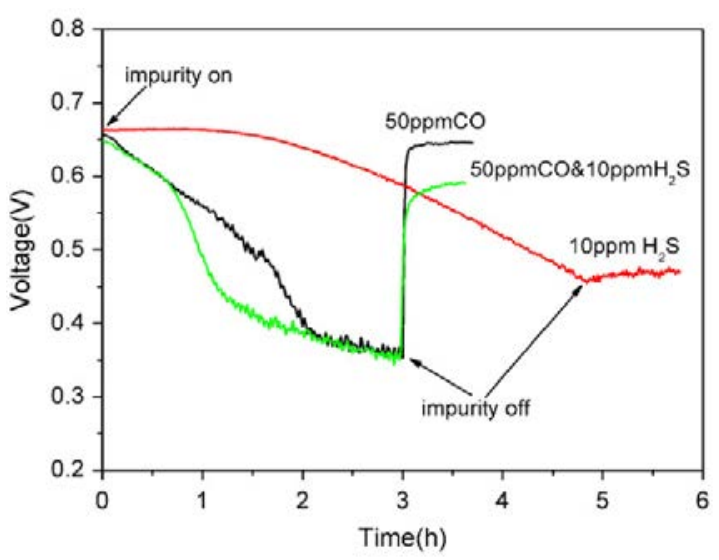

Fig. 6. Comparison of the effects of $50 \mathrm{ppm} \mathrm{CO}, 10 \mathrm{ppm}_{2} \mathrm{~S}$, and the gas mixture (50 ppm $\mathrm{CO}$ and $10 \mathrm{ppm}_{2} \mathrm{~S}$ ) on the performances of a PEMFC. $j=600 \mathrm{~mA} \mathrm{~cm}^{-2}, T_{\text {cell }}=60^{\circ} \mathrm{C}$, operating pressure: $P=0.1 \mathrm{MPa}$, humidification temperatures of the anode and cathode: $T=25$ and $60{ }^{\circ} \mathrm{C}$, respectively.
A pulses every $0.8 \mathrm{~s}$ to a cell with a $\mathrm{H}_{2} / \mathrm{CO}_{2} / \mathrm{CO}$ inlet. The overpotential decreased, but was not supressed. Shi et al. [74] tried to apply pulses in potential to a $\mathrm{H}_{2} \mathrm{~S}$-poisoned cell, recovering $97 \%$ of the initial current. It was later found that those oxidation peaks however, can damage the electrocatalyst layer and enhance the dissolution of some of its components [83]; cyclic voltammetry leads to a similar issue. This real sensitivity of Pt-based electrocatalysts to fast potential changes is now well documented in the literature, both in acidic [84-88] and alkaline [88-90] media. This demonstrate the very deleterious and somewhat irreversible effect of $\mathrm{H}_{2} \mathrm{~S}$ on state-of-the-art Pt-based electrocatalysts.

Consequently, it is essential to limit the $\mathrm{H}_{2} \mathrm{~S}$ impurities in the hydrogenous fuels of an EHC (and a PEMFC). A generally-accepted method is to mix $\mathrm{ZnO}$ with inert substances, such as $\mathrm{SiO}_{2}$, to create a hydrogen sulphide scavenging module [92]. Numerous adsorbents $[93,94]$ are suggested for this operation: all processes are based on TSA methods, and reduce the overall productivity of gas separation process [95]. Capture of $\mathrm{H}_{2} \mathrm{~S}$ at room temperature remains a great scientific challenge [96] though, and the reader will understand that it cannot be addressed with more details in the present contribution.

\section{Tolerant materials}

The best way not to damage the catalyst layer is still to adapt it to tolerate those impurities. Apart from the effect of ammonia, all poisons affect the Pt-based electrocatalyst, which has thus to be strengthened. Many materials, and additives were tested in order to reduce the effect of carbon monoxide towards $\mathrm{Pt}$, and one could go further by saying that if a catalyst is tolerant to $\mathrm{CO}$, it will also be tolerant to $\mathrm{CO}_{2}$ (which is not true in the reverse case). The $\mathrm{H}_{2} \mathrm{~S}$ tolerance however, was only scarcely studied.

In the $\mathrm{CO}$ oxidation mechanism, the limiting step is not the one of $\mathrm{CO}$ oxidation, but the adsorption of hydroxyl groups that is necessary to strip the CO adsorbates (Eqs. (5) and (6)). Anderson et al. [97] calculated that even though the activation energy of reaction (22) increases with the potential, the overall activation energy would decrease. It is in fact due to the adsorption of $\mathrm{OH}$, that only starts at $E=0.6 \mathrm{~V} v s$ RHE on platinum. Assuming this, the first main strategy to enhance the CO-tolerance of Pt-based electrocatalysts, is to find a co-catalyst able to adsorb those hydroxyl groups at much lower potential, and oxidize $\mathrm{CO}_{\text {ads. }}$ The second strategy is to weaken the Pt-CO bond, in order to facilitate its oxidation, or even prevent its initial adsorption [98]. This could be achieved by increasing the platinum nanoparticle size [99], or by creating agglomerates of nanoparticles [100], and thus increasing the amount of concave Pt sites, with a weak CO-bond. Adapting the structure and morphology of the catalyst can enhance its electroactivity towards a reaction, and in particular the tolerance to $\mathrm{CO}$ (or the CO-oxidation activity) [101].

Alloying Pt with a less noble catalyst can help to achieve both strategies. By changing Pt electronic structure, the Pt-CO bond is weakened, and components adsorbed on less noble metal site can diffuse towards Pt sites. Many PtM alloys were 
tested, with $\mathrm{M}=\mathrm{Ru}, \mathrm{Ir}, \mathrm{V}, \mathrm{Rh}, \mathrm{Cr}, \mathrm{Co}, \mathrm{Ni}, \mathrm{Fe}, \mathrm{Os}, \mathrm{Mn}, \mathrm{Pd}, \mathrm{W}$, Mo, $\mathrm{Sn}, \mathrm{Au}$ [102-105]. In nearly all those cases PtRu was found to be the best solution, as shown in Fig. 7(a), from Iwase's work. It has been studied for a long time [77,106-110] and in many different conditions. With the optimum ratio of (1:1), it can oxidise CO as low as at $E=0.59 \mathrm{~V}$ vs RHE at ambient temperature with a $20 \mathrm{mV} \mathrm{s}^{-1}$ scan rate. Papageorgopoulos et al. [44] found that with a $\mathrm{CO}_{2}$-contaminated feed, $\mathrm{PtRu} / \mathrm{C}$ could retain $85 \%$ of its sites while Pt/C retained only $22 \%$ in the same conditions. Dubau et al. [111] even found that alloying was not mandatory, Pt-Ru composites supported on carbon also exhibiting improved activity versus CO-oxidation, or more specifically in that case to methanol, being admitted that methanol fast dehydrogenation at the electrocatalyst surfaces leaves COad. With $\mathrm{H}_{2} \mathrm{~S}$ however, there was no difference with Pt/C [112]. As of today, this PtRu alloy (or composite) is still the main reference when it comes to CO-tolerance (and tolerance to small hydrocarbon molecules), and is even used in commercial applications. Its main drawback might be its poor stability, and the associated Ru dissolution problems [113].

Some other alloys have been studied, like Pt3Sn [114]-[116].

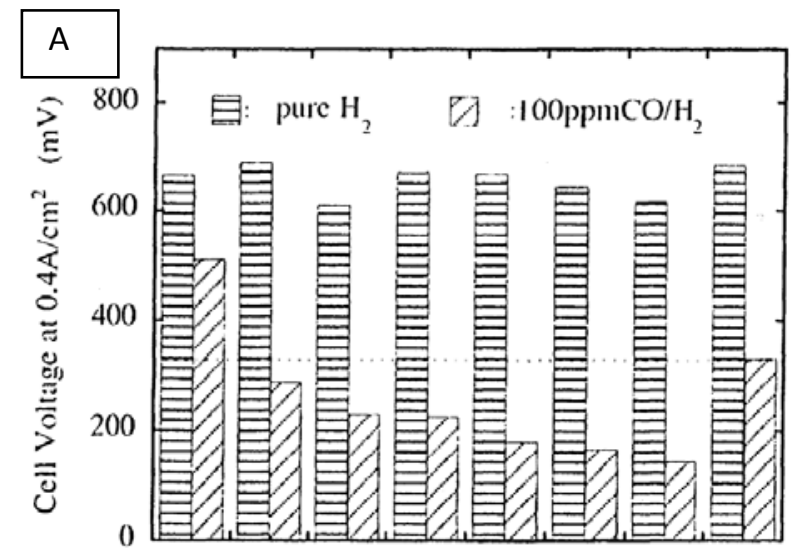

Pt-Ru Pt-Ir Pt-V Pt-Rh Pt-Cr Pt-Co Pt-Ni Pt

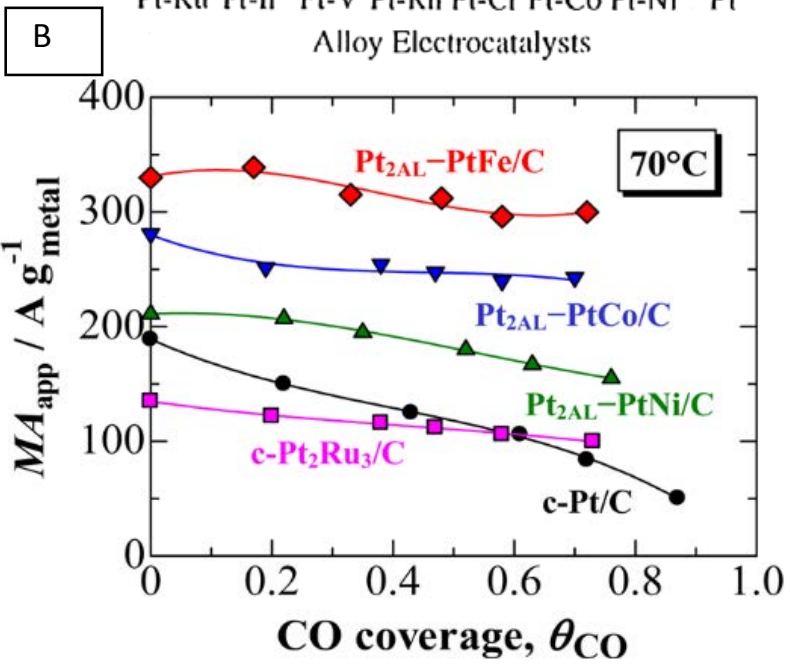

Fig. 7. (A) Cell voltages of alloy electrocatalysts in hydrogen or $100 \mathrm{ppm}$ $\mathrm{CO} / \mathrm{H}_{2}$ oxidation in PEMFC configuration. All anode alloy electrocatalysts are made of $20 \mathrm{wt} \%$ alloy/C (Vulcan XC72R) with Pt loading rate of $0.4 \mathrm{mgt} \mathrm{cm}^{-2}$. Cathodes electrocatalysts are made of $20 \mathrm{wt} \% \mathrm{Pt} / \mathrm{C}$ [104]; (B) Dependence of the apparent mass activity $\mathrm{MA}_{\text {app }}$ at $20 \mathrm{mV}$ vs RHE of several electrocatalysts on CO coverage at Nafion-coated electrodes measured in $\mathrm{H} 2$-saturated $0.1 \mathrm{M} \mathrm{HClO}_{4}$ solution at $70{ }^{\circ} \mathrm{C}$ [122].
CO having no affinity with Sn sites, the surface is free to adsorb hydroxyl groups, thus decreasing the onset oxidation potential of $\mathrm{CO}$ to $E=0.3 \mathrm{~V}$ vs RHE. $\mathrm{Pt}_{3} \mathrm{Sn}$ gives however, very poor PEMFC performance, probably owing to a much reduced HOR activity versus $\mathrm{Pt} / \mathrm{C}$, and because of its poor stability $\mathrm{Sn}$ cannot be used alone or in composites. PtMo was also found interesting, because of its increased activity towards CO [117-121]. Mukerjee found an optimum ratio of 3:1 for this alloy. There is however no clear data on its activity towards HOR, and Nepel's results showed a slight performance loss in a PEMFC. Sometimes a third or even fourth element is added to the alloy, in order to improve either its activity and/or stability [83,122,123]. By adding Ru or Fe in PtMo, Hassan et al. [122] effectively achieved an increased activity towards HOR. Several experiments were also made by adding Pt atomic layers on top of an alloy, as shown Fig. 7(b).

Without changing platinum properties, it is also possible to enhance CO oxidation by changing the supporting material. Replacing carbon black with metal oxides such as $\mathrm{RuO}_{x}, \mathrm{WO}_{x}$, $\mathrm{SnO}_{x}, \mathrm{MoO}_{x}$ or $\mathrm{FeO}_{x}$ [124-129], proved to create electrocatalysts with performance sometimes better than for PtRu. $\mathrm{Pt} / \mathrm{WO}_{3}$ for example, despite its poor stability, proved to free part of the Pt sites as soon as $E=0.1 \mathrm{~V} v$ s RHE (Fig. 8(A)), an outstanding performance $([130,131])$; its stability was however not as impressive. When synthetizing a new morphology, like Sugimoto's team did with $\mathrm{RuO}_{2}$ and $\mathrm{Ru}$ nanosheets, even $\mathrm{PtRu}$ can have its performance increased in a $300 \mathrm{ppm} \mathrm{CO} / \mathrm{H}_{2}$ gas mixture (Fig. 8(B)), but the behaviour of this material at $\mathrm{CO}$ concentrations experienced in an EHC remains unknown. For all these oxide supports though, two main drawbacks need to be taken into account: the poor durability and the low electronic conductivity.

Other additional components were tested with Pt, under CO-poisoning conditions. Polymorphins for example, do not participate in the HOR activity, but when added in the optimal amount, they helped Pt to oxidise $\mathrm{CO}$ as soon as $E=0.08 \mathrm{~V}$ vs RHE $[133,134]$, a very impressive performance; the study however does not grants that the HOR activity of the Pt component is not altered by these compounds.

Many materials have been optimized towards the CO (or methanol) tolerance at a fuel cell anode. Changing Pt properties or environment proves to be a good solution to achieve low-potential oxidation of this poison. Those new electrocatalysts shapes/compositions, however, are not always very stable under working conditions, or have a short lifespan. What's more, the studies were often performed at small concentration of pollutant (well below compositions needed for an EHC purification device), usually for CO only, and proper HOR activity measurements still need to be done for all these new electrocatalysts, in order to compare them in front of the EHC application, where very large HOR current density must be employed.

\section{HOR electrocatalyst materials and means to relevantly study the HOR kinetics}

With the EHC application, the aim is to reach current densities (much) higher than $j=1 \mathrm{~A} \mathrm{~cm}^{-2}$ in order to stay competi- 


\section{A}

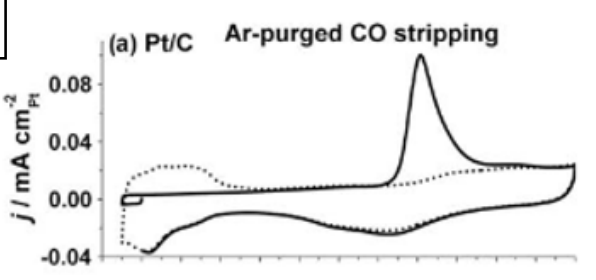

(b) PtRu/C
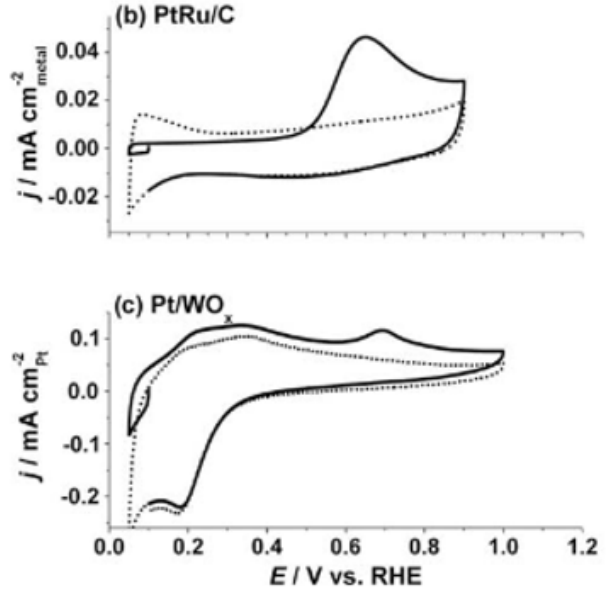

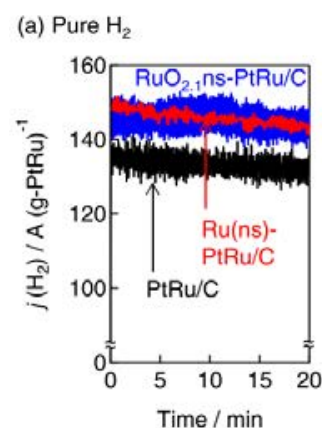

(b) $300 \mathrm{ppm} \mathrm{CO} / \mathrm{H}_{2}$
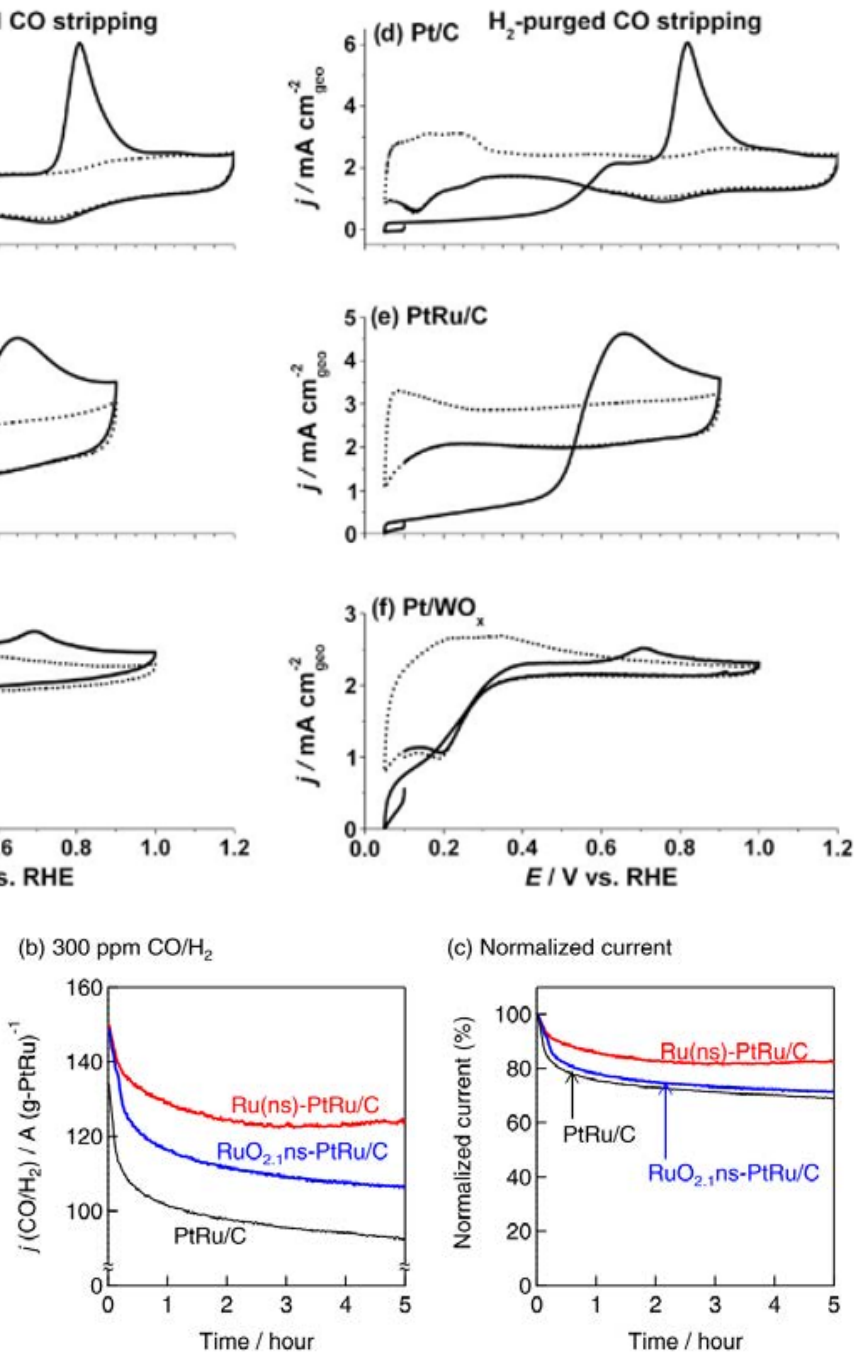

(c) Normalized current

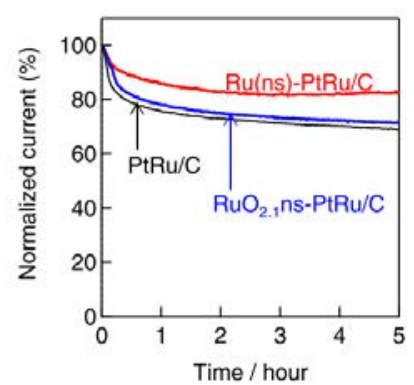

Fig. 8. (A) comparison of the $\mathrm{CO}$ tolerance of $\mathrm{Pt} / \mathrm{C}, \mathrm{PtRu} / \mathrm{C}$ and $\mathrm{Pt} / \mathrm{WO}_{3}$ [130]. (B) comparison of the $\mathrm{CO}$ tolerance of $\mathrm{PtRu} / \mathrm{C} \mathrm{RuO}{ }_{2} \mathrm{~ns}-\mathrm{PtRu} / \mathrm{C}$ and Runs-PtRu/C [132].

tive towards other purification/compression technologies. To that goal, the HOR activity, for which Pt/C is known to be the best electrocatalyst, is of pivotal importance. Few experiments dealing with the poison-tolerance of Pt-based electrocatalysts also addressed the HOR activity, since compared to the oxygen reduction reaction, the HOR was never the limiting reaction in a fuel cell. Only some studies tried to change the cathode inlet for $\mathrm{H}_{2}$ (the so-called hydrogen pump setup) in order to properly study the influence of impurities on the HOR. Resulting overpotential values are shown Table 2. Those results, however, have to be read with carefulness, considering the significant differences between both studies, notably in terms of operating conditions.

It must be noted though, that the impurities tested in these cases are not the most critic ones, and that other studies with $\mathrm{CO}, \mathrm{H}_{2} \mathrm{~S}$, etc. are yet to be made in these experimental conditions.

Several complementary methods exist that can help to compare some electrocatalysts activity for the HOR.

The rotating disk electrode (RDE) is mostly used for kinet- ics/mechanistic analysis. Its facile utilisation permits a fast study of a wide range of catalysts, and the 3 electrode-cell setup enables a good control over the reaction. In this case, all reactions happen in a liquid electrolyte, sometimes saturated with gases when needed. Hydrogen and other gases diffusion in water is however extremely low compared to the gas phase, leading to severe mass-transport limitations. Although these can be corrected for the reduction of oxygen, a reaction of slow charge transfer kinetics [135], reactions of very fast charge-transfer kinetics like the HOR have no chances not to be limited by mass-transport kinetics. This transport limitation thus forbids any study of the HOR kinetics in the RDE configuration ([136,137]). Results presented in section 2.2.2 and Fig. 7 are thus interesting to compare electrocatalysts behaviour towards impurities, but cannot give a comparison relevant enough for the EHC application.

The floating electrode technique was developed by Zalitis et al. $[27,138,139]$ to overcome the inherent mass-transport limitations experienced in RDE. It consists of a 3-electrode cell with liquid electrolyte with a working electrode made of a porous 
Table 2

Measured overpotential values at the anode of a PEMFC in hydrogen pump configuration $\left(\mathrm{H}_{2}\right.$ inlet at the cathode).

\begin{tabular}{lcccc}
\hline $\begin{array}{l}\text { Electro- } \\
\text { catalyst }\end{array}$ & $\begin{array}{c}\text { Loading } \\
\left(\mathrm{mg} / \mathrm{cm}^{2}\right)\end{array}$ & Gas inlet & $\begin{array}{c}\text { Overpotential } \\
\text { at } 1 \mathrm{~A} / \mathrm{cm}^{2}\end{array}$ & Ref. \\
\hline $\mathrm{Pt}$ & 0.4 & $80 \% \mathrm{H}_{2}+20 \% \mathrm{~N}_{2}$ & $7 \mathrm{mV}$ & {$[35]$} \\
$\mathrm{Pt}$ & 0.4 & $80 \% \mathrm{H}_{2}+20 \% \mathrm{CO}_{2}$ & $15 \mathrm{mV}$ & {$[35]$} \\
$\mathrm{PtRu}$ & 0.45 & $100 \% \mathrm{H}_{2}$ & $13 \mathrm{mV}$ & {$[45]$} \\
$\mathrm{PtRu}$ & 0.45 & $75 \% \mathrm{H}_{2}+25 \% \mathrm{~N}_{2}$ & $14 \mathrm{mV}$ & {$[45]$} \\
$\mathrm{PtRu}$ & 0.45 & $75 \% \mathrm{H}_{2}+25 \% \mathrm{CO}_{2}$ & $30 \mathrm{mV}$ & {$[45]$} \\
\hline
\end{tabular}

material that floats on the electrolyte surface. It permits direct contact between the gas and liquid phases at the electrocatalyst surface. The very low loadings of electrocatalyst employed $(0.1$ to $10 \mu \mathrm{g} \mathrm{cm}^{-2}$ of $\mathrm{Pt}$ ) helps to reach the charge-transfer limits of the HOR kinetics, and thus the methodology can lead to HOR kinetics determination and provide a proper toolbox to compare different HOR electrocatalysts materials. To the authors' knowledge, the technique has not been used in presence of impurities, yet, so more work must be done on that matter.

The gas diffusion electrode, developed by Inaba et al. [140], provides that same control over a small deposited amount of electrocatalyst, while providing reactants in a similar way to PEMFC set-up. However, it has still, to the authors' knowledge, not been used to characterize the HOR, and even less the HOR in presence of impurities.

The last method is to use a full PEMFC set-up and to control or measure the potential difference between both electrodes when operated in hydrogen pump $([82,136,137,141])$. This is the most realistic method to access the HOR kinetics, especially considering the water content and non-limited gas transport. When studying the anode side however, the cathode limitations and crossover problems may forbid a clear measurement of the anode electrocatalyst influence. Also, such method is not necessarily appropriate to analyse the reaction mechanisms at work (because the two electrodes can be limiting at the same time), which would be needed in order to improve the electrocatalyst correctly.

\section{Conclusions}

The part I of the present contribution "Electrochemical hydrogen compression and purification versus competing technologies: Part I. pros and cons" enabled to highlight that, (1) among the different means to purify and compress hydrogen, the electrochemical hydrogen compressor (EHC) exhibits a wealth of assets and (2) the performances of present EHC systems are still not ideal and must be improved. This is particularly the case with regards to the membrane, which must be more robust and selective to enable both high compression ratio and purification, but even more with regards to the anode electrocatalyst of the purification cell. Because the electrocatalyst materials in an EHC (and in particular at the anode of the purification stage that operates in impure hydrogen) needs to operate at the maximal current density (ideally $j>>1 \mathrm{~A} \mathrm{~cm}^{-2}$ ), at the lowest possible electrode potential (ideally $E<0.5 \mathrm{~V}$ ) in the presence of many contaminants, it must exhibit unique performances. The literature is very rich about the poison tolerance of Pt-based electrocatalysts for the PEMFC. However, almost none of these studies are necessarily adapted to describe the particular case of an EHC used for the purification and compression of hydrogen; to be more specific, they usually address model cases where either the contaminant feed is insufficiently concentrated or the HOR current targeted is too low (or even not mentioned) to fully correspond to the case of an EHC purification/compression cell. Whatever these biases, these studies enable to shed light on the required characteristics these electrocatalysts should exhibit and on the techniques one should use to develop and study these materials. It is particularly emphasized that to experience the very large current densities needed for an EHC, testing electrocatalysts materials solely with the rotating disk electrode setup (in which one basically only monitors the hydrogen mass-transport limitation but not its charge-transfer kinetics) is highly insufficient. Instead, advanced techniques like the floating electrode of $\mathrm{Ku}$ cernak et al., the gas-diffusion electrode of Arenz et al. or the hydrogen pump of Gasteiger et al. are mandatory (but still not widespread in their usage, unfortunately).

\section{Acknowledgments}

The authors thank the Auvergne Rhône-Alpes region for the funding of the PhD thesis of Marine Trégaro. Part of the work has been performed within the framework of the Centre of Excellence of Multifunctional Architectured Materials "CEMAM" no. ANR-10-LABX-44-01. Both MT and MR make their PhD in the frame of the Eco-Sesa project, funded by IDEX Université Grenoble Alpes.

\section{Nomenclature}

ECSA ElectroChemically active Surface Area

EHC Electrochemical Hydrogen Compressor

HER Hydrogen Evolution Reaction

HOR Hydrogen Oxidation Reaction

MEA Membrane Electrode Assembly

PEM Proton Exchange Membrane

PEMFC Proton Exchange Membrane Fuel Cell

TSA Temperature Swing Adsorption

RDE Rotating Disc Electrode

RHE Reversible Hydrogen Electrode

RWGS Reverse Water Gas Shift

\section{References}

[1] "Home | California Fuel Cell Partnership." [Online]. Available: https://cafcp.org/. [Accessed: 19-Feb-2019].

[2] "Development of the new model of a residential fuel cell, 'ENE-FARM,'” Tokyo Gas : Technical Development/Comfortable housing and lifestyle - Residential Sector. [Online]. Available: https://www.tokyo-gas.co.jp/techno/english/menu3/2_index_de tail.html. [Accessed: 19-Feb-2019].

[3] "Fuel cell and hydrogen technology: Europe's journey to a greener world," presented at the 10th Stakeholder Forum I Fuel Cells and 
Hydrogen Joint Undertaking, 2017.

[4] A. F. Ghoniem, Prog. Energy Combus. Sci., 2011, 37, 15-51.

[5] S. Z. Baykara, Int. J. Hydrogen Energy, 2018, 43, 10605-10614.

[6] R. Łukajtis, I. Holowacz, K. Kucharska, M. Glinka, P. Rybarczyk, A. Przyjazny, M. Kaminski, Renew. Sustainable Energy Rev., 2018, 91, 665-694.

[7] J.-P. Magnin, J. Deseure, Appl. Energy, 2019, 239, 635-643.

[8] S. Zhang, L. Wang, C. Liu, J. Luo, J. Crittenden, X. Liu, T. Cai, J. Yuan, Y. Pei, Y. Liu, Water Res., 2017, 121,11-19.

[9] C. Vacquand, E. Deville, V. Beaumont, F. Guyot, O. Sissmann, D. Pillot, C. Arcilla, A. Prinzhofer, Geochim. Cosmochim. Acta, 2018, 223, 437-461.

[10] "U.S. Department of Energy."

[11] "ISO 14687-2:2012: Hydrogen fuel -- Product specification -- Part 2: Proton exchange membrane (PEM) fuel cell applications for road vehicles." 2012.

[12] "ISO 14687-3:2014: Hydrogen fuel -- Product specification -- Part 3: Proton exchange membrane (PEM) fuel cell applications for stationary appliances." 2014.

[13] G. Sdanghi, G. Maranzana, A. Celzard, V. Fierro, Renew. Sustainable Energy Rev., 2019, 102, 150-170.

[14] B. A. T. Mehrabadi, H. N. Dinh, G. Bender, J. W. Weidner, J. Electrochem. Soc., 2016, 163, F1527-F1534.

[15] T. Reshetenko, A. Serov, K. Artyushkova, I. Matanovic, Sarah Stariha, P. Atanassov, J. Power Sources, 2016, 324, 556-571.

[16] O. A. Baturina, B. Dyatkin, T. V. Reshetenko, in: Nanostructured Materials for Next-Generation Energy Storage and Conversion: Fuel Cells, F. Li, S. Bashir, J. L. Liu, Eds. Berlin, Heidelberg: Springer Berlin Heidelberg, 2018, 407-441.

[17] R. Tuominen, N. Helppolainen, J. Ihonen, J. Viitakangas, Int. J. Hydrogen Energy, 2018, 43, 4143-4159.

[18] J. Qi, Y. Zhai, J. St-Pierre, J. Power Sources, 2019, 413, 86-97.

[19] M. Chatenet, L. Dubau, N. Job, F. Maillard, Catal. Today, 2010, 156, 76-86

[20] F. Maillard, S. Pronkin, E. R. Savinova, in: Fuel Cell Catalysis, M. T. M. Koper, Ed. Hoboken, NJ, USA: John Wiley \& Sons, Inc., 2009, 507-566.

[21] P. J. Ferreira, G. J. la O', Y. Shao-Horn, D. Morgan, R. Makharia, S.
Kocha, H. A. Gasteiger, J. Electrochem. Soc., 2005, 152, A2256.

[22] L. Dubau, L. Castanheira, F. Maillard, M. Chatenet, O. Lottin, G. Maranzana, J. Dillet, A. Lamibrac, J. Perrin, E. Moukheiber, A. ElKaddouri, G. De Moor, C. Bas, L. Flandin, N. Caque, Wiley Interdisciplinary Reviews: Energy Environment, 2014, 3, 540-560.

[23] F. Maillard, S. Pronkin, E. R. Savinova, in: Hbook of Fuel Cells, W. Vielstich, A. Lamm, H. A. Gasteiger, H. Yokokawa, Eds. Chichester, John Wiley \& Sons, Ltd, 2010.

[24] E. Guilminot, A. Corcella, M. Chatenet, F. Maillard, F. Charlot, G. Berthome, C. Iojoiu, J.-Y. Sanchez, E. Rossinot, E. Claude, J. Electrochem. Soc., 2007, 154, B1106.

[25] E. Guilminot, A. Corcella, F. Charlot, F. Maillard, M. Chatenet, J. Electrochem. Soc., 2007, 154, B96

[26] Y. Sun, Y. Dai, Y. Liu, S. Chen, Phys. Chem. Chem. Phys., 2012, 14, 2278.

[27] C. M. Zalitis, J. Sharman, E. Wright, A. R. Kucernak, Electrochim. Acta, 2015, 176, 763-776.

[28] B. M. Besancon, V. Hasanov, R. Imbault-Lastapis, R. Benesch, M. Barrio, M. J. Mølnvik, Int. J. Hydrogen Energy, 2009, 34, 2350-2360.

[29] S. Abbou, J. Dillet, D. Spernjak, R. Mukundan, R. L. Borup, G. Maranzana, O. Lottin, J. Electrochem. Soc., 2015, 162, F1212-F1220.

[30] S. Abbou, J. Dillet, G. Maranzana, S. Didierjean, O. Lottin, J. Power Sources, 2017, 340, 419-427.

[31] S. Abbou, J. Dillet, G. Maranzana, S. Didierjean, O. Lottin, J. Power Sources, 2017, 340, 337-346.

[32] S. Um, C.-Y. Wang, K. S. Chen, J. Electrochem.Soc., 2000, 147, 4485.

[33] X. Cheng, Z. Shi, N. Glass, L. Zhang, J. Zhang, D. Song, Z. Liu, H. Wang, J. Shen, J. Power Sources, 2007, 165, 739-756.

[34] C. Y. Chen, W. H. Lai, W. M. Yan, C. C. Chen, S. W. Hsu, J. Power Sources, 2013, 243, 138-146.

[35] T. Gu, W.-K. Lee, J. W. Van Zee, M. Murthy, J. Electrochem. Soc., 2004, 151, A2100.

[36] T. Tingelöf, L. Hedström, N. Holmström, P. Alvfors, G. Lindbergh, Int. J. Hydrogen Energy, 2008, 33, 2064-2072.

[37] B. Ibeh, C. Gardner, M. Ternan, Int. J. Hydrogen Energy, 2007, 32, 908-914

[38] C.-Y. Chen, K.-P. Huang, J. Appl. Electrochem., 2018, 48, 911-921.

\section{Graphical Abstract}

\section{Chin. J. Catal., 2020, 41: 770-782 doi: S1872-2067(19)63438-8}

Electrochemical hydrogen compression and purification versus competing technologies: Part II. Challenges in electrocatalysis

Marine Trégaro, Maha Rhandi, Florence Druart, Jonathan Deseure, Marian Chatenet*

Univ. Grenoble Alpes, Univ. Savoie Mont Blanc, France

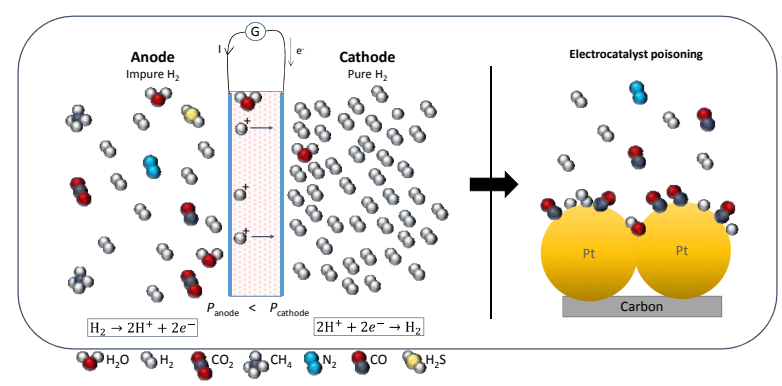

Electrochemical hydrogen purification-compression systems require anode electrocatalysts that are tolerant to impurities very active for hydrogen oxidation reaction. This contribution reviews potential electrocatalysts for this application, but also methods to efficiently characterize them. 
[39] J. Giner, Electrochim. Acta, 1963, 8, 857-865.

[40] F. A. de Bruijn, D. C. Papageorgopoulos, E. F. Sitters, G. J. M. Janssen, J. Power Sources, 2002, 110, 117-124.

[41] T. Gu, W. K. Lee, J. W. Van Zee, Appl. Catal. B, 2005, 56, 43-49.

[42] M. A. Díaz, A. Iranzo, F. Rosa, F. Isorna, E. López, J. P. Bolivar, Energy, 2015, 90, 299-309.

[43] W.-M. Yan, H.-S. Chu, M.-X. Lu, F.-B. Weng, G.-B. Jung, C.-Y. Lee, J. Power Sources, 2009, 188, 141-147.

[44] D. C. Papageorgopoulos, F. A. de Bruijn, J. Electrochem. Soc., 2002, 149, A140.

[45] R. Halseid, R. Tunold, J. Electrochem. Soc., 2006, 153, A2319.

[46] N. Zamel, X. Li, Prog. Energy Combus. Sci., 2018, 37, 292-329.

[47] J. J. Baschuk, X. Li, Int. J. Energy Res., 2001, 25, 695-713.

[48] S. Gilman, J. Phys. Chem., 1964, 68, 70-80.

[49] G. Karimi, X. Li, J. Power Sources, 2006, 159, 943-950.

[50] R. Benesch, S. Salman, T. Jacksier, 2006, 1-11.

[51] R. Halseid, P. J. S. Vie, R. Tunold, J. Power Sources, 2006, 154, 343-350.

[52] F. A. Uribe, S. Gottesfeld, T. A. Zawodzinski, J. Electrochem. Soc., 2002, 149, A293.

[53] H. J. Soto, W. Lee, J. W. Van Zee, M. Murthy, Electrochem. Solid-State Lett., 2003, 6, A133.

[54] R. Halseid, P. J. S. Vie, R. Tunold, J. Electrochem. Soc., 2004, 151, A381.

[55] D. Imamura, Y. Matsuda, Y. Hashimasa, M. Akai, ECS Trans., 2011, 41, 2083-2089.

[56] V. Rosca, M. T. M. Koper, Phys. Chem. Chem. Phys., 2006, 8, 2513.

[57] Y. A. Gomez, A. Oyarce, G. Lindbergh, C. Lagergren, J. Electrochem. Soc., 2018, 165, F189-F197.

[58] T. E. Springer, T. Rockward, T. A. Zawodzinksi, S. Gottesfeld, J. Electrochem. Soc., 2001, 148, L9.

[59] W. Vogel, J. Lundquist, P. Ross, P. Stonehart, Electrochim. Acta, 1975, 20, 79-93.

[60] M. Murthy, M. Esayian, W. Lee, J. W. Van Zee, J. Electrochem. Soc., 2003, 150, A29.

[61] L. Dubau, F. Maillard, Electrochem. Commun., 2016, 63, 65-69.

[62] W. H. Scholz, Gas Sep. Purif., 1993, 7, 131-139.

[63] W. Yourong, Y. Heqing, W. E'feng, J. Electroanal. Chem., 2001, 497, 163-167.

[64] R. Jayaram, A. Q. Contractor, H. Lal, J. Electroanal. Chem., 1978, 87, 225-237.

[65] E. Najdeker, E. Bishop, Electroanal. Chem. Interfacial Electrochem., 1973, 41, 79-87.

[66] T. Loucka, Electroanal. Chem. Interfacial Electrochem., 1971, 31, 319-332.

[67] W. Shi, B. Yi, M. Hou, F. Jing, H. Yu, P. Ming, J. Power Sources, 2007, 164, 272-277.

[68] V. A. Sethuraman, J. W. Weidner, Electrochim. Acta, 2010, 55, 5683-5694.

[69] R. Mohtadi, W. K. Lee, J. W. Van Zee, Appl. Catal. B, 2005, 56, 37-42.

[70] A. A. Shah, F. C. Walsh, J. Power Sources, 2008, 185, 287-301.

[71] I. G. Urdampilleta, F. A. Uribe, T. Rockward, E. L. Brosha, B. S. Pivovar, F. H. Garzon, ECS Trans., 2007, 11, 831-842.

[72] K. K. Bhatia, C. Y. Wang, Electrochim. Acta, 2004, 49, 2333-2341.

[73] G. J. M. Janssen, J. Power Sources, 2004, 136, 45-54.

[74] W. Shi, B. Yi, M. Hou, Z. Shao, Int. J. Hydrogen Energy, 2007, 32, 4412-4417.

[75] X. Wang, P. Baker, X. Zhang, H. F. Garces, L. J. Bonville, U. Pasaogullari, T. M. Molter, Int. J. Hydrogen Energy, 2014, 39, 19701-19713.

[76] D. Imamura, Y. Hashimasa, ECS Trans., 2007, 11, 853-862.
[77] M. S. Wilson, C. R. Derouin, J. Valerio, S. Gottesfeld, in: Proceedings of the 28th Intersociety Energy conversion engineering conference, Atlanta, Georgia, 1993, 1203-1208.

[78] S. Gottesfeld, J. Pafford, J. Electrochem. Soc., 1988, 135, 2651.

[79] P. A. Adcock, S. V. Pacheco, K. M. Norman, F. A. Uribe, J. Electrochem. Soc., 2005, 152, A459.

[80] J. J. Baschuk, X. Li, Int. J. Energy Res., 2003, 27, 1095-1116.

[81] T. Lopes, V. A. Paganin, E. R. Gonzalez, J. Power Sources, 2011, 196, 6256-6263.

[82] C. L. Gardner, M. Ternan, J. Power Sources, 2007, 171, 835-841.

[83] A. Hassan, V. A. Paganin, E. A. Ticianelli, Electrocatalysis, 2015, 6, 512-520.

[84] F. R. Nikkuni, B. Vion-Dury, L. Dubau, F. Maillard, E. A. Ticianelli, M. Chatenet, Appl. Catal. B, 2014, 156-157, 301-306.

[85] F. R. Nikkuni, L. Dubau, E. A. Ticianelli, M. Chatenet, Appl. Catal. B, 2015, 176-177, 486-499.

[86] A. A. Topalov, S. Cherevko, A. R. Zeradjanin, J. C. Meier, I. Katsounaros, K. J. J. Mayrhofer, Chem. Sci., 2014, 5, 631-638.

[87] S. Cherevko, G. P. Keeley, S. Geiger, A. R. Zeradjanin, N. Hodnik, N. Kulyk, K. J. J. Mayrhofer, ChemElectroChem, 2015, 2, 1471-1478.

[88] S. Cherevko, A. R. Zeradjanin, G. P. Keeley, K. J. J. Mayrhofer, J. Electrochem.Soc., 2014, 161, H822-H830.

[89] A. Zadick, L. Dubau, N. Sergent, G. Berthomé, M. Chatenet, ACS Catal., 2015, 5, 4819-4824.

[90] C. Lafforgue, A. Zadick, L. Dubau, F. Maillard, M. Chatenet, Fuel Cells, 2018, 18, 229-238.

[91] M. Schalenbach, O. Kasian, M. Ledendecker, F. D. Speck, A. M. Mingers, K. J. J. Mayrhofer, S. Cherevko, Electrocatalysis, 2018, 9, 153-161.

[92] C. Yang, J. Wang, H. Fan, Y. Hu, J. Shen, J. Shangguan, B. Wang, Energy Fuels, 2018, 32, 6064-6072.

[93] C. Babé, M. Tayakout-Fayolle, C. Geantet, M. Vrinat, G. Bergeret, T. Huard, D. Bazer-Bachi, Chem. Eng. Sci., 2012, 82, 73-83.

[94] H. A. Aleksrov, P. St. Petkov, G. N. Vayssilov, Energy Environ. Sci., 2011, 4, 1879.

[95] A. Golmakani, S. Fatemi, J. Tamnanloo, Sep. Purif. Technol., 2017, 176, 73-91.

[96] T. Yamamoto, M. Tayakout-Fayolle, C. Geantet, Chem. Eng. J., 2015, 262, 702-709.

[97] A. B. Anderson, E. Grantscharova, J. Phys. Chem., 1995, 99, 9143-9148.

[98] D. A. Tryk, G. Shi, H. Yano, J. Inukai, H. Uchida, A. Iiyama, M. Matsumoto, H. Tanida, M. Arao, H. Imai, ECS Trans., 2018, 85, 41-46.

[99] F. Maillard, M. Eikerling, O. V. Cherstiouk, S. Schreier, E. R. Savinova, U. Stimming, Faraday Disc., 2004, 125, 357.

[100] F. Maillard, S. Schreier, M. Hanzlik, E. R. Savinova, S. Weinkauf, U. Stimming, Phys. Chem. Chem. Phys., 2005, 7, 385-393.

[101] S. Brimaud, S. Pronier, C. Coutanceau, J. M. Léger, Electrochem. Commun., 2008, 10, 1703-1707.

[102] L. G. S. Pereira, V. A. Paganin, E. A. Ticianelli, Electrochim. Acta, 2009, 54, 1992-1998.

[103] G. García, J. A. Silva-Chong, O. Guillén-Villafuerte, J. L. Rodríguez, E. R. González, E. Pastor, Catal. Today, 2006, 116, 415-421.

[104] S. Iwase, M., Kawatsu, In Proceedings of the first International Symposium on proton conducting membrane fuel cells, 1995, 1, 12-18.

[105] S. Carenco, Chem. Eur. J., 2014, 20, 10616-10625.

[106] M. Watanabe, S. Motoo, Electroanal. Chem. Interf. Electrochem., 1975, 60, 275-293.

[107] H. A. Gasteiger, N. Markovic, P. N. Ross, E. J. Cairns, J. Phys. Chem., 
1994, 98, 617-625.

[108] H. A. Gasteiger, N. M. Markovic, P. N. Ross, J. Phys. Chem., 1995, 99, 16757-16767.

[109] H. A. Gasteiger, N. Markovic, P. N. Ross, E. J. Cairns, J. Phys. Chem., 1993, 97, 12020-12029.

[110] T. Kawaguchi, W. Sugimoto, Y. Murakami, Y. Takasu, Electrochem. Commun., 2004, 6, 480-483.

[111] L. Dubau, F. Hahn, C. Coutanceau, J.-M. Léger, C. Lamy, J. Electroanal. Chem., 2003, 554-555, 407-415.

[112] R. Mohtadi, W. -k. Lee, S. Cowan, J. W. Van Zee, M. Murthy, Electrochem. Solid-State Lett., 2003, 6, A272.

[113] L. Gancs, B. N. Hult, N. Hakim, S. Mukerjee, Electrochem. Solid-State Lett., 2007, 10, B150.

[114] H. A. Gasteiger, N. M. Markovic, P. N. Ross, J. Phys. Chem., 1995, 99, 8945-8949.

[115] K. Wang, H. A. Gasteiger, N. M. Markovic, P. N. Ross, Electrochim. Acta, 1996, 41, 2587-2593.

[116] D. Lee, S. Hwang, I. Lee, J. Power Sources, 2005, 145, 147-153.

[117] E. I. Santiago, G. A. Camara, E. A. Ticianelli, Electrochim. Acta, 2003, 48, 3527-3534.

[118] E. I. Santiago, M. S. Batista, E. M. Assaf, E. A. Ticianelli, J. Electrochem. Soc., 2004, 151, A944.

[119] R. C. Urian, A. F. Gullá, S. Mukerjee, J. Electroanal. Chem., 2003, 554-555, 307-324.

[120] S. Mukerjee, R. C. Urian, S. J. Lee, E. A. Ticianelli, J. McBreen, J. Electrochem. Soc., 2004, 151, A1094.

[121] T. C. M. Nepel, P. P. Lopes, V. A. Paganin, E. A. Ticianelli, Electrochim. Acta, 2013, 88, 217-224.

[122] A. Hassan, E. A. Ticianelli, Anais da Academia Brasileira de Ciencias, 2018, 90, 697-718.

[123] M. Götz, H. Wendt, Electrochim. Acta, 1998, 43, 3637-3644.

[124] T. Ioroi, Z. Siroma, S. Yamazaki, K. Yasuda, Adv. Energy Mater., 2018, 1801284 .
[125] T. Ioroi, T. Akita, S. Yamazaki, Z. Siroma, N. Fujiwara, K. Yasuda, Electrochim. Acta, 2006, 52, 491-498.

[126] L. Liu, F. Zhou, R. Kodiyath, S. Ueda, H. Abe, D. Wang, Y. Deng, J. Ye, Phys. Chem. Chem. Phys., 2016, 18, 29607-29615.

[127] K. Kwon, Y. Jung, H. Ku, K. H. Lee, S. Kim, J. Sohn, C. Pak, Catalysts, 2016, 6, 68

[128] D. Takimoto, T. Ohnishi, Y. Ayato, D. Mochizuki, W. Sugimoto, J. Electrochem. Soc., 2016, 163, 367-371.

[129] F. Micoud, PhD Thesis, 2009.

[130] F. Micoud, F. Maillard, A. Gourgaud, M. Chatenet, Electrochem. Commun., 2009, 11, 651-654.

[131] F. Micoud, F. Maillard, A. Bonnefont, N. Job, M. Chatenet, Phys. Chem. Chem. Phys., 2010, 12, 1182-1193.

[132] D. Takimoto, T. Ohnishi, W. Sugimoto, ECS Electrochem. Lett., 2015, 4, F35-F37.

[133] S. I. Yamazaki, Y. Yamada, S. Takeda, M. Goto, T. Ioroi, Z. Siroma, K. Yasuda, Phys. Chem. Chem. Phys., 2010, 12, 8968-8976.

[134] S. Yamazaki, M. Yao, S. Takeda, Z. Siroma, T. Ioroi, K. Yasuda, Electrochem. Solid-State Lett., 2011, 14, B23.

[135] F. Gloaguen, F. Andolfatto, R. Durand, P. Ozil, J. Appl. Electrochem., 1994, 24, 863-869.

[136] J. Durst, A. Siebel, C. Simon, F. Hasché, J. Herranz, H. A. Gasteiger, Energy Environ. Sci., 2014, 7, 2255-2260.

[137] J. Durst, C. Simon, F. Hasché, H. A. Gasteiger, J. Electrochem. Soc., 2015, 162, F190-F203.

[138] C. M. Zalitis, D. Kramer, A. R. Kucernak, Phys. Chem. Chem. Phys., 2013, 15, 4329-4340.

[139] A. R. Kucernak, C. M. Zalitis, J. Phys. Chem. C, 2016, 120, 10721-10745.

[140] M. Inaba, A. W. Jensen, G. W. Sievers, M. Escudero-Escribano, A. Zana, M. Arenz, Energy Environ. Sci., 2018, 11, 988-994.

[141] K. C. Neyerlin, W. Gu, J. Jorne, H. A. Gasteiger, J. Electrochem. Soc., 2007, 154, B631.

\title{
电化学氢压缩和纯化与竞争技术的对比: II. 电催化的挑战
}

\author{
Marine Trégaro, Maha Rhandi, Florence Druart, Jonathan Deseure, Marian Chatenet * \\ 格勒诺布尔阿尔卑斯大学, 勃朗峰大学, CNRS, Grenoble-INP, LEPMI, 38000格勒诺布尔, 法国
}

\begin{abstract}
摘要: 在未来的几十年里, 氢将成为世界能源政策的基础, 因为它的脱碳性质, 至少在可再生能源生产时是如此. 目前, 氢 基本上仍然是从化石原料中生产出来的(在某种程度上来自于生物质); 因此, 目前市场上的氢气含有不可忽略的杂质, 这 些杂质阻碍了氢气立即用于特殊化学或作为燃料电池的能量载体, 例如在运输应用(汽车、公共汽车、火车、船只等)中逐 渐扩散到地球上. 因此, 氢气必须具有足够的纯度, 但也必须充分压缩(在高压下, 通常为70 MPa), 这使得氢气循环中不可 避免存在净化和压缩步骤. 如本文第一部分 “电化学氢压缩和净化与竞争技术的对比一一第一部分: 优缺点”所示, 电化学 氢压缩机(EHCs)能够实现氢净化和压缩, 具有比它们相应的机械设备更多的理论(热力学)和实际(动力学)的优越性. 然而, 为了具有竞争力, EHCs必须在非常密集的条件下运行(高电流密度和低电池电压), 只有在其核心材料(如膜和电极/电催化 剂)经过优化后才能达到. 本文将特别关注电催化剂在EHCs中必须表现出的特性: 在杂质存在的情况下它们应促进(非常) 快速的氢氧化反应(HOR), 这意味着它们对毒物也具有(非常)耐受性. 这包括操作氢气净化压缩所用的EHC阳极的先决条 件, 而大量低温燃料电池文献中为耐受毒性而开发的材料可能并不总是满足这两个标准, 正如本综述所阐述的.
\end{abstract}

关键词: 电化学氢压缩; 电化学氢纯化; 电催化剂; 氢氧化; 毒物耐受性

收稿日期: 2019-05-20. 接受日期: 2019-07-03. 出版日期: 2020-05-05.

*通讯联系人. 电子信箱: Marian.Chatenet@grenoble-inp.fr

本文的电子版全文由Elsevier出版社在ScienceDirect上出版(http://www.sciencedirect.com/science/journal/18722067). 